\title{
教育講演
}

\section{5. 老人性肺炎診療の新戦略}

\author{
佐々木英忠
}

Key words : サブスタンスP，ドーパミン，イミダプリル，アマンタジン

\section{はじめに}

65 歳以上老人の人口 1,900 万人の内 $11 \% に$ 当たる 200 万人が要介護老人である。この要介 護老人 200 万人のめに, 平成 12 年より介護保 険が作られようとしている．要介護老人の直接 死因として最大な疾患は肺炎であり，肺炎は日 本人死因の男性で第 3 位, 男女共で第 4 位と重 要な疾患である，又，肺炎の死亡の92\%は65歳 以上の老人で占められることから，肺炎は老人 の友と 100 年前に米国の臨床家オスラーが名言 した通りになっている。

老人性肺炎は従来起炎菌の固定と抗生物質を いかに使用するかに重点がおかれてきたが，一 旦治療してもすぐ再発し, 難治性グラム陰性保 菌が起炎菌におきかわり，収束がつかなくなる ことが多い.

本稿ではオスラーの名言にあえて挑戦し，老 人性肺炎の子防法の確立を目標に，老人性成立 機序を解明し, 肺炎発症を $1 / 3 \sim 1 / 4$ に減少で きた成績を紹介する。

\section{1. 老人性肺炎発症機序}

古くより脳卒中直後に肺炎が起こりやすいこ
とは知られていたが，老人性肺炎を起こす人は 脳血管障害特に大脳基底核の脳血管障害を持っ ている人に多くみられる1".大脳皮質にいくら 障害があっても肺炎にはいたらない，大脳基底 核は穿通枝領域でもともと脳梗塞を起こしやす い部位であるが，大脳基底核の障害はこの部位 にある黒質線状体から産生されるドーパミンが 少なくなる2). ドーパミン産生の減少は，迷走 神経知覚枝から咽頭や気管に放出されるサブス タンスP (SP) の量を減少させる3). 実際，老 人性肺炎をおこした患者から強制的に排出した 喀痰中のサブスタンスPは低い4)．SPは嚥下反 射と咳反射の原動力となる物質であるため, SP の減少は嬹下反射と咳反射を低下させる.塞際， 老人性肺炎患者では嚥下反射と咳反射の低下が

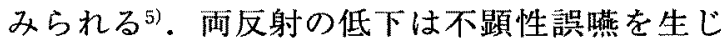
ることになる ${ }^{6)}$ こそして，1年間のうちには高 率に肺炎を起こしやすくなり，特に両側大脳基 底核の脳血管障害に扮いて著しい1（図 1).

以上より，老人性肺炎の肺炎は最初に大血管 障害があり，ドーパミンの低下，SPの低下， そして不顕性誤嶼で肺炎にいたると考えられ た。つまり老人性肺炎は単なる結果であり，大 脳基底核の脳血管障害が原因であるともいえ る. 


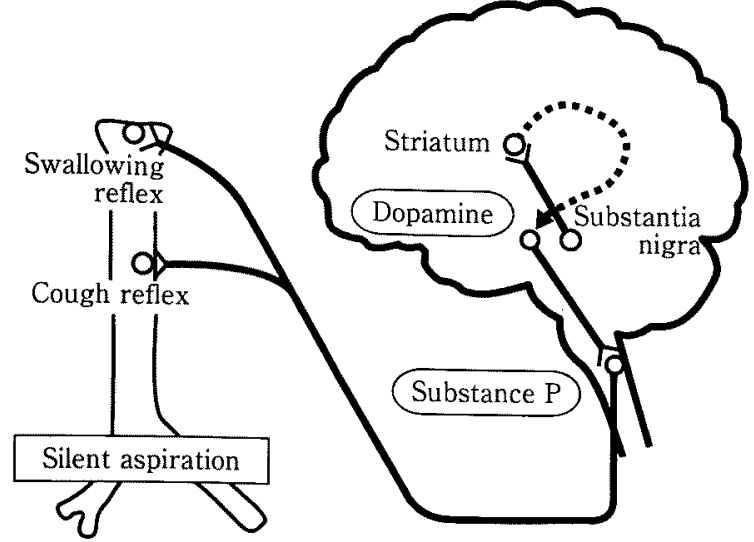

Glossopharyngeal sensory nerve Vagal sensory nerve

図 1.老人性肺炎の病態

\section{ACE阻害薬による老人性肺资発症予防}

脳血管障害から肺炎にいたるまでの経路が判 明したのであるから，その経路にそって，不足 の物質を補充してやることによって不顕性䛊曣 を予防し，肺炎予防になると考えられる。

第 1 にSPが少ないのであるから，SPを強力
に放出させるカプサイシン少量投与を行っ た7).カプサイシンをロ腔内に少量投与したの みで, 嚥下反射は正常化し，著明な改善をみた。 このことは，老年者ではある程度辛い物を食べ ることによってSPが放出され，嚥下反射は正 常化し，不顕性誤睢を予防できることになると 考えられた，カプサイシンは唐辛子そのもので ある。

老人性肺炎患者において，低下しているSP を上昇させるもう 1 つの薬物はACE (angiotensin converting enzyme) 阻害薬である.

ACE阻害薬はSPの分解酵素も阻害してしま うため，SPが分解されず，濃度が高くなり， 老人性肺炎患者でも，SPが正常化し，與下反 射が正常化したと考えられた8)。高血圧があ り，大脳基底核に脳血管障害がある老年者 440 人を選出し，一方 (217人)にはACE阻害楽（イ ミダプリル）を，他方（313人）にはCa拮抗薬 や阻害薬を降圧効果が得られるまで各種投与 した. 2年間の経過観察の成績は図 2 のごとく でACE阻害薬内服者は, 非内服者に比べて, 約1/3に肺炎羅患率を減少させだ．同様に漢

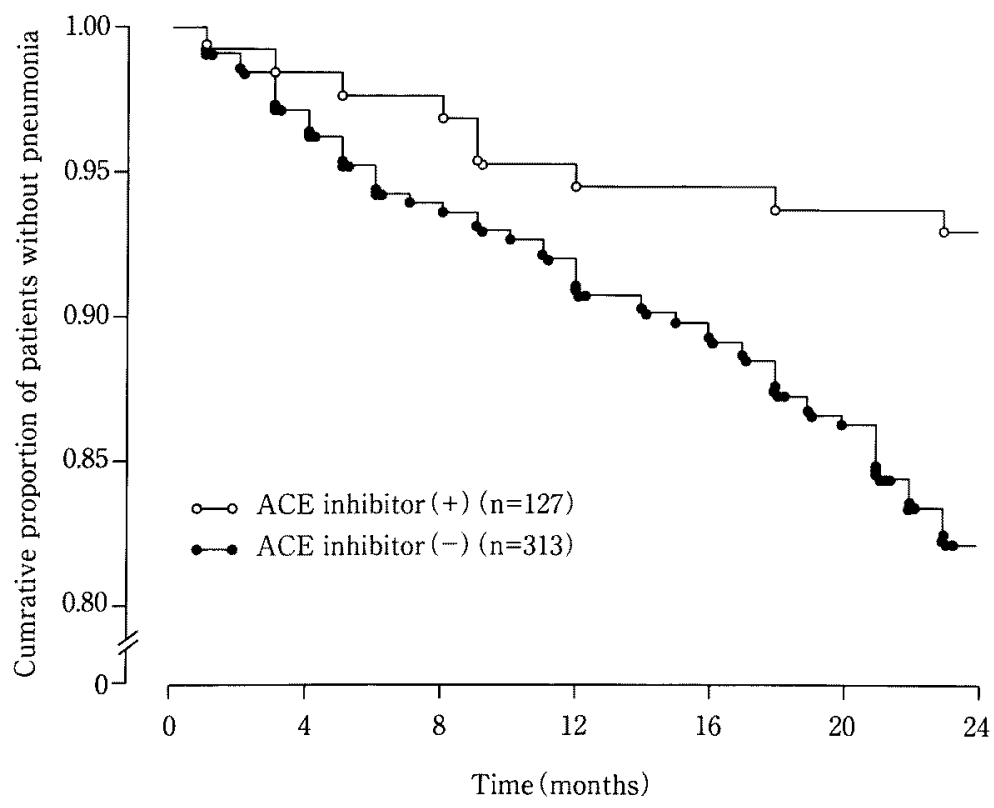

図 2.イミダプリルを 2 年間投与して（○）肺炎発生を非投与群（○）に比べて $1 / 3$ に滅少させた. 


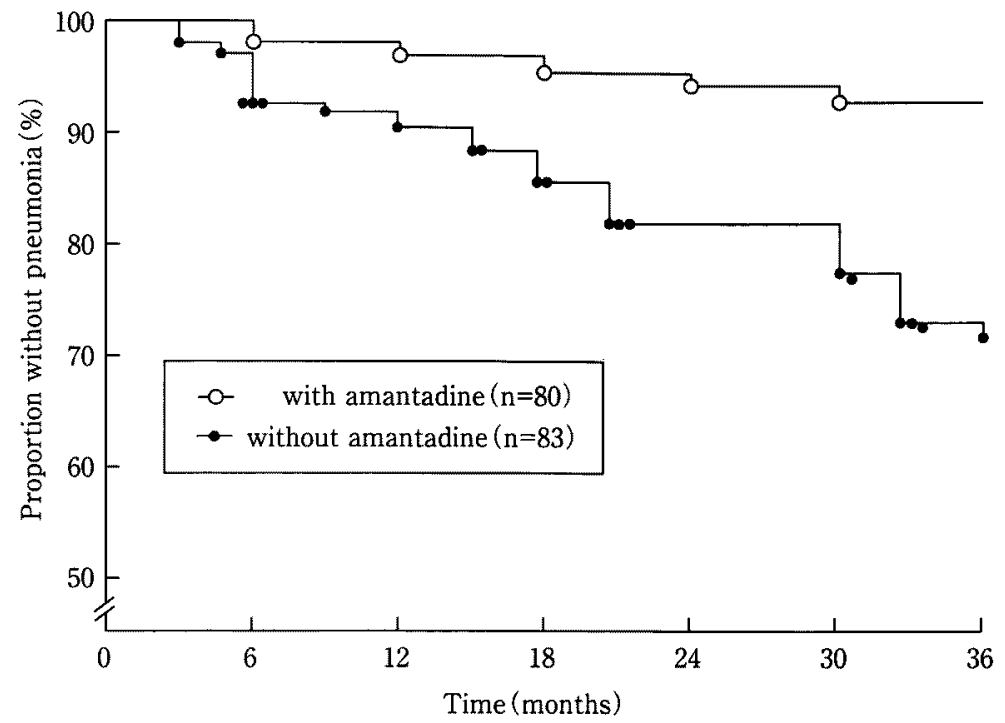

図 3.アマンタジン投与 3 年間で投与群（○）は非投与群（○）に比べて肺炎を $1 / 5$ に隇少させた.

方等の半夏厚朴湯においても $\mathrm{ACE}$ 阻害薬と同 じ効果が得られている10).

\section{3. アマンタジンによる老人性肺炎予防}

老人性肺炎患者において低下しているSPを 上昇させるもう一つの薬物はドーパミン製剤で ある．老年者で高血圧がありこれまで肺炎に 罹患した人を対象に，ドーパミンを補充した。 レポドパ50mgを $20 \mathrm{ml}$ の生食に混ぜて 30 分〜 1 時間かけて点滴静注した後, 嚥下反射を測定し たところ，嚥下反射は有意に改善した11)。これ は不顕性誤嚥を予防し, 肺炎を薬物で予防でき る方法と考えられた。

老年者で高血圧があり，大脳基底核に脳血管 障害を持っている人，183人を対象に，一群（n =80）にアマンタジン100mg分 2 で1995年 1 月 から投与開始した。他群 $(\mathrm{n}=83)$ には何も投 与しなかった．通常の抗圧薬はそのまま投与し た. 結果は図 3 の如くで, 3 年間の追跡調查の 結果, アマンタジン非投与群は 22 人 (28\%) 肺 炎をおこしたのに，アマンタジン投与群では 5 人（6\%）しか肺炎をおこさなかった12).
アマンタジンは時に幻覚, 妄想をおこす副作 用がある.しかし，それは150～200 $\mathrm{mg}$ と多量 投与の場合であり，100mgでは特記すべき副作 用はなかった，又，アマンタジンはインフルエ ンザA型に対する治療成績が報告されている. しかし，インフルエンザは多くの種類があり， 又, 流行も一時的である. 図 3 の成績は 3 年間 の長期にわたっており，インフルエンザA型を 含んでいると考えられた

\section{4. インフルエンザワクチンの効果}

高龄者特に寝たきり老人にインフルエンザワ クチンを投与しても効果はあるのか否か疑問の ところであるが，私共は寝たきり老人でも細胞 性免疫は低下するが液性免疫は低下しないこと を $^{14)}$ ，インフルエンザワクチンにより抗体価は 十分若者と同時に上昇すること ${ }^{15)}$ ，そして，肺 炎をはじめとする冬期の呼吸器症状を有意に軽 減させることを証明した ${ }^{16)}$ (図 4). 従ってい くら寝たきり老人でもインフルエンザワクチン の効果は若い人と同時に存在するため今後用い られるべきと結論された。 


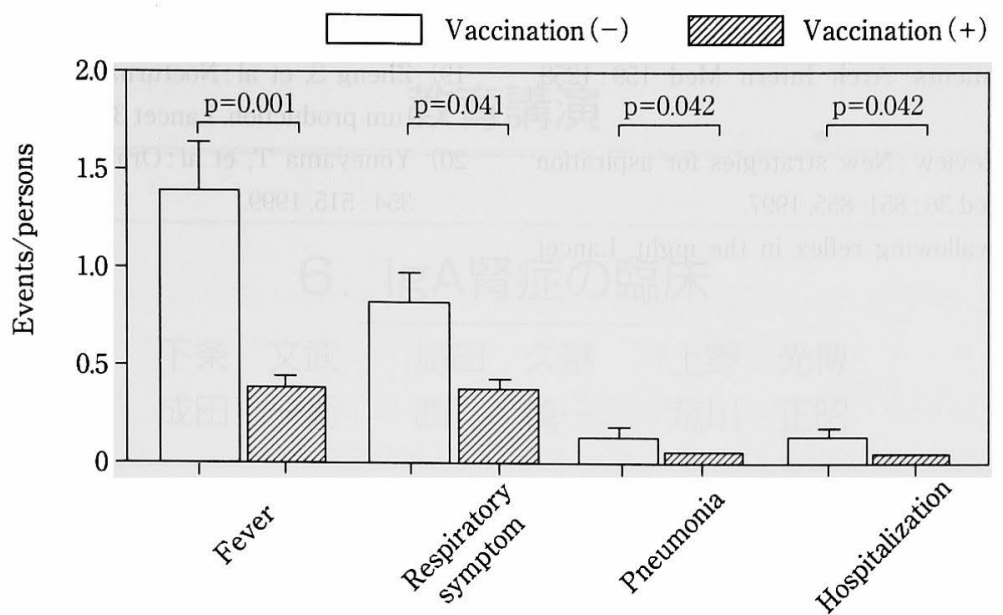

図 4.インフルエンザワクチン接種により冬期 4 カ月間呼吸器症状や肺炎を有意に減少させた.

おわりに

\section{老人性肺炎は要介護老人が死亡する直前の} 疾患であり，それ以前の人には無関係と考えら れてきたが, 最近脳ドック検診の報告によれば, 65歳以上の健康者の約半数に大脳基底核の口イ コアライオーシスなど何らかの脳血管障害がみ られるとMRI (magnetic resonance imaging) 画像で報告されている.65歳以上では妙におこ りっぽくなったり，友人の葬式で黙㤽などをす ることが多くなるが，目をつぶったとたんに体 がゆれるなどの症状が多く出現するようにな る.このような人は大脳基底核のドーパミン減 少がありえ，肺炎になる可能性が高いとも考え られる．老人性肺炎は65歳以上であれば身近な 疾患である ${ }^{17)}$. 睡眠薬の投与はドーパミンを抑 制し，不顕性誤嚥を発生させ易くなる ${ }^{18,19)}$ 。こ のためせめて夜寝る前だけでも口腔ケアをする ことによって肺炎は40\%減少させえる20).

\section{文献}

1) Nakagawa $T$, et al : High incidence of pneumonia in elderly patients with basal ganglia infarction. Arch Intern Med 157 : 321-324, 1997.

2) Ito $\mathrm{M}$, Ido $\mathrm{T}$ : First signs of Alzheimers? Science 259:
898, 1993.

3) Jia YX, et al: Dopamine D, receptor antagonist inhibits swallowing reflex in guinea pigs. Am J Physiol 43 : R76R80, 1998.

4) Nakagawa $T$, et al: Sputum substance $P$ in aspiration pneumonia. Lancet $345:$ 1447, 1995.

5) Sekizawa $K$, et al: Lack of cough reflex in aspiration pneumonia. Lancet 335 : 1228-1229, 1990.

6) Kikuchi $\mathrm{R}$, et al: High incidence of silent aspiration in elderly patients with community acquired pneumonia. Am J Respir Crit Care Med 150 : 251-253, 1994.

7) Ebihara $T$, et al : Capsaicin and swallowing reflex. Lancet $341: 432,1993$.

8) Nakayama K, et al : ACE inhibitor and swallowing reflex. Chest $113: 1425,1998$.

9) Sekizawa K, et al : ACE inhibitors and pneumonia. Lancet $352: 1069,1998$.

10) Iwasaki $K$, et al: The traditional Chinese medicine Banxia Houpo Tang improves swallowing reflex phyto medicine. 6 : 103-106, 1999.

11) Kobayashi $\mathrm{H}$, et al: Levodopa and swallowing reflex. Lancet 348: 1320-1321, 1996.

12) Nakagawa $T$, et al: Amantadine and pneumonia. Lancet $363: 1157,1999$.

13) Sekizawa $K$, et al : Amantadine and pneumonia in elderly stroke patients. Lancet $353: 2157,1999$.

14) Fukushima $T$, et al: Depression of $T$ helper-1 and tuberculin responses in older bed-bound patients. JAGS 47 : 259-260, 1999.

15) Fukushima $T$, et al: Influenza vaccination in bedridden patients. Arch Intern Med 159: 316-317, 1999. 
16) Fukushima $T$, et al: Benefits of influenza vaccination for bedridden patients. Arch Intern Med 159:1258, 1999.

17) Sasaki $\mathrm{H}$, et al: Review : New strategies for aspiration pneumonia. Int Med $36: 851-855,1997$.

18) Pinto $A$, et al: Swallowing reflex in the night. Lancet
$344: 820-821,1994$.

19) Zheng $S$, et al : Nocturnal cough in patients with sputum production. Lancet 350:864-865, 1997.

20) Yoneyama $T$, et al: Oral care and pneumonia. Lancet $354: 515,1999$. 